\title{
MUELLER $V \cdot$ ALLEN: A NEW STANDARD OF SCRUTINY APPLIED TO TAX DEDUCTIONS FOR EDUCATIONAL EXPENSES
}

In the past thirty-seven years ${ }^{1}$ the United States Supreme Court has confronted a variety of state legislative schemes attempting to aid sectarian schools either through a direct subsidy to the school ${ }^{2}$ or through aid to the parents and students who patronize the schools. ${ }^{3}$ Opponents of such legislation consistently contend that state aid to sectarian schools offends the establishment clause of the first amendment. ${ }^{4}$ While holding many of these schemes unconstitutional, the Court has validated several forms of aid to nonpublic schools. ${ }^{5}$ Unfortunately, the Court's tests for determining the constitutionality of such legislation remaim imprecise. ${ }^{6}$

1. The Court first addressed the constitutionality of state aid to sectarian schools in Everson v. Board of Educ., 330 U.S. 1 (1947). Although the Court had applied the first amendment to the states through the fourteenth amendment on previous occasions, see Murdock v. Pennsylvania, 319 U.S. 105 (1943) (freedoms of speech, press, and religion); Cantwell v. Connecticut, 310 U.S. 296 (1940) (freedom of religion, freedom to believe, and freedom to act), Everson was the first tine that the Court utilized the fourteenth amendment to incorporate the establishment clause, 330 U.S. at 14-15.

2. See Committee for Pub. Educ. \& Religious Liberty v. Regan, 444 U.S. 646 (1980) (reimbursement for the costs of standardized testing); Wolman v. Walter, 433 U.S. 229 (1977) (reimbursement for the costs of testing, diagnostic services, and textbook loans); Meek v. Pittenger, 421 U.S. 349 (1975) (rennbursement for the costs of auxiliary services, textbook loans, and instructional materials); Levitt v. Committee for Pub. Educ. \& Religious Liberty, 413 U.S. 472 (1973) (reimbursement for costs of testing); Lemon v. Kurtzman, 403 U.S. 602 (1971) (salary supplement to teachers).

3. See Committee for Pub. Educ. \& Religious Liberty v. Nyquist, 413 U.S. 756 (1973) (tuition tax "credit"); Board of Educ. v. Allen, 392 U.S. 236 (1968) (textbook loans to students); Everson v. Board of Educ., 330 U.S. 1 (1947) (transportation costs reimbursed).

4. The first clause of the first amendment is referred to as the establishment clause: "Congress shall make no law respecting an establishment of religion . . ." U.S. CoNsT. amend. I.

5. Examples of aid that the Court has found constitutionally permissible include reimbursement of transportation expenses, Everson v. Board of Educ., 330 U.S. 1,17 (1947), aid for diagnostic services, Wolman v. Walter, 433 U.S. 229, 244 (1974), reimbursement for the costs of standardized testing, Committee for Pub. Educ. \& Religious Liberty v. Regan, 444 U.S. 646, 648 (1980), and textbook loan programs, Wolman, 433 U.S. at 238.

6. In Nyquist, Justice Powell stated that "while there has been general agreement upon the applicable principles and upon the framework of analysis, the Court has recognized its inability to perceive with invariable clarity the "limes of demarcation in this extraordimarily sensitive area of constitutional law.'" Committee for Pub. Educ. \& Religious Liberty v. Nyquist, 413 U.S. 756, 761 n.5 (1973) (quoting Lemon v. Kurtzman, 403 U.S. 602, 612 (1971)). 
The Court has had particular difficulty formulating a precise test for statutes granting tax relief to the parents of students attending nonpublic schools. Although it held tax credits for tuition unconstitutional in Committee for Public Education and Religious Liberty v. Nyquist, ${ }^{7}$ the Court specifically reserved the question whether tax deductions for tuition would be constitutionally acceptable. ${ }^{8}$ Not surprisingly, after Nyquist, a conflict developed between the United States Courts of Appeals for the Eighth ${ }^{9}$ and First Circuits ${ }^{10}$ over the constitutionality of virtually identical state statutes granting such deductions. ${ }^{11}$ The Supreme Court resolved this conflict in Mueller $v$. Allen. ${ }^{12}$

7. 413 U.S. 756, 794, 798 (1973). The New York tax benefit resembled a tax deduction, but the Court concluded that it was similar in operation to a tax credit. See id. at 789.

8. Id. at 790 n.49.

9. Mueller v. Allen, 676 F.2d 1195 (8th Cir. 1982) (tuition tax deduction constitutional), affd, 103 S. Ct. 3062 (1983).

10. Rhode 1sland Fed'n of Teachers v. Norberg, 630 F.2d 855 (1st Cir. 1980) (tuition tax deduction unconstitutional).

11. The Eighth Circuit case involved a Minnesota statute that allowed the following deduction from a taxpayer's gross imcome:

Tuition and transaction expense. The amount he has paid to others, not to exceed $\$ 500$ for each dependent in grades $\mathrm{K}$ to 6 and $\$ 700$ for each dependent in grades 7 to 12 , for tuition, textbooks and transportation of each dependent in attending an elementary or secondary school situated in Minnesota, North Dakota, South Dakota, lowa, or Wisconsin, wherein a resident of this state inay legally fulfill the state's compulsory attendance laws, which is not operated for profit, and which adheres to the provisions of the Civil Rights Act of 1964 and chapter 363. As used in this subdivision, "textbooks" shall mean and include books and other instructional materials and equipment used in elementary and secondary schools in teaching only those subjects legally and commonly taught in public elementary and secondary schools in this state and shall not include instructional books and materials used in the teaching of religious tenets, doctrimes or worship, the purpose of which is to inculcate such tenets, doctrines or worship, nor shall it mclude such books or materials for, or transportation to, extracurricular activities including sportimg events, inusical or dramatie events, speech activities, driver's education, or programs of a similar nature.

MinN. STAT. \$ 290.09(22) (1982). The First Circuit case addressed a similar Rhode Island tax statute:

Modification Reducing Federal Adjusted Gross Income - There shall be subtracted from federal adjusted gross income...

(2) amounts paid to others, not to exceed five hundred $(\$ 500)$ dollars for each dependent in kindergarten through sixth grade and seven hundred $(\$ 700)$ dollars for each such dependent in grades seven through twelve inclusive, for tuition, textbooks, and transportation of each dependent attending an elementary or secondary school situated im Rhode Island, Massachusetts, Counecticut, Vernont, New Hainpshire or Maine, wherem a resident of this state inay legally fulfill the state's coinpulsory attendance laws, which is not operated for profit, and which adheres to the provision of the Civil Rights Act of 1964. As used in this section, "textbooks" shall inean and include books and other instructional inaterials and equipinent used in eleinentary and secondary schools in teaching only those subjects legally and commonly taught in public elementary and secondary schools im this state and shall not include instructional books and inaterials used in the teaching of rehgious tenets, doctrines, or worship, the purpose of which is to inculcate such tenets, doctrines or worship.

R.I. GEN. LAWS § 44-30-12(c)(2) (1980).

12. 103 S. Ct. 3062, 3064 (1983). 
Specifically, the Mueller Court held that such statutes do not violate the establishment clause. ${ }^{13}$ In reaching this result, the Court utilized the traditional three-part test of constitutionality under the establishment clause, ${ }^{14}$ but applied a less strict standard of scrutiny than it had applied in previous cases. This note analyzes the potential effects of this new standard. Section one presents the Court's traditional three-part test. Section two describes the less strict standard of scrutiny applied in Mueller, and section three analyzes the possible effects the new standard will have on state and federal aid to sectarian schools.

\section{THE Lemon Three-Part Test}

The estabhishment clause of the first ainendment contains broad language: "Congress shall inake no law respecting an establishment of religion ...."15 The term "respecting" indicates that the drafters of the amendinent desired to prohibit not only laws that directly establish religion, but also laws that represent a step leading to such an establishment. ${ }^{16}$ In the absence of further guidance froin the framers the task of defining the limits of the clause has fallen on the Supreme Court.

The Court has experienced particular difficulty in determining whether aid that benefits sectarian schools, rather than directly benefiting rehigion itself, falls withm the sweeping language of the establishment clause. In Everson v. Board of Education, ${ }^{17}$ the Court addressed this issue for the first time. Finding no standards on which to base a decision, the Court in Everson turned to an historical analysis of the period during which the first ainendinent was drafted to find the purpose of the clause. ${ }^{18}$ From this analysis, the Court reasoned that the first amendment requires the state "to be neutral in its relations with groups of religious believers and non-believers." 19 Using this "neutral-

\section{Id.}

14. Id. at 3066 .

15. U.S. CONST, amend. I.

16. See Lemon v. Kurtzman, 403 U.S. 602, 612 (1971).

17. 330 U.S. 1 (1947) (state reimbursements of transportation expenses for children attending religious schools).

18. Id. at 8-16. The Court concluded:

[t] he "establishment of religion" clause of the First Amendment means at least this: ... [n]o tax in any amount, large or small, can be levied to support any religious activities or institutions, whatever they may be called, or whatever form they inay adopt to teach or practice religion. Neither a state nor the Federal Government can, openly or secretly, participate in the affairs of any religious organizations or groups and vice versa. In the words of Jefferson, the clause against cstablishment of religion by law was intended to erect "a wall of separation between church and State."

Id. at 15-16 (citation omitted).

19. Id. at 18 . 
ity" analysis, the Court determined that the law in question was neutral and therefore that it was constitutional. ${ }^{20}$ This simplistic analysis forced the Court to judge the constitutionality of statutes on a case-bycase basis; it did not provide standards useful to test the constitutionality of other laws. As a result, the Court developed three separate tests in an attempt to give consistency to its interpretations of the establishinent clause.

The Supreme Court consolidated these three establishment clause tests imto a single three-part test in Lemon v. Kurtzman:"1 "First, the statute inust have a secular legislative purpose; second, its principal or primary effect inust be one that neither advances nor inhibits religion; finally, the statute must not foster 'an excessive government entangleinent with religion." "22 Subsequent Supreme Court decisions refined each subtest's function; one must understand these functions to appreciate Mueller's potential impact.

\section{A. The Secular Purpose Test.}

The Supreme Court utilizes the Everson neutrality analysis ${ }^{23}$ when applying the secular purpose test. ${ }^{24}$ The test is satisfied if a court finds a legislative purpose that neither inhibits nor advances religion. ${ }^{25}$ To find such legislative purposes a court slould examine the intention of the legislature when it passed the law. ${ }^{26}$ Express statements of legislative purpose in a statute, though not binding on the court, are imdicative of legislative intent. ${ }^{27}$ The Supreme Court las also accepted

20. Id. Although recognizing the possibility that the transportation program might assist children in attending church schools and the possibility that some children might not attend the church schools if their parents were forced to pay transportation costs, the Court compared the transportation program to general government services such as police and fire protection. Id. at 17-18. The Court found that withdrawal of the services would detrimentally affect the church schools, violating the first amendment's requirement that state power be exercised neutrally; "[s]tate power is no more to be used so as to handicap religions than it is to favor them." Id. at 18 . Therefore, the transportation program, like other governmental services, did not violate the first amendinent even though it benefitted children attending sectarian schools.

21. 403 U.S. 602 (1971).

22. Id. at $612-13$ (citations omitted).

23. For a discussion of the neutrality analysis and the holding in Everson, see supra note 20 and accompanying text.

24. Abington School Dist. v. Scheinpp, 374 U.S. 203 (1963), first introduced the secular purpose requirement. In that opinion, the Court cited Everson as the foundation for the test. Id. at 222; see Board of Educ. v. Allen, 392 U.S. 236, 243 (1968).

25. Abington School Dist. v. Schcmpp, 374 U.S. 203, 222 (1963).

26. Lemon, 403 U.S. at 613 (imtention of legislature determined by language of statute).

27. See Hunt v. McNair, 413 U.S. 734, $741-42$ (1973) ("while a legislature's declaration of purpose may not always be a fair guide to its true imtent, appellant makes no suggestion that the introductory paragraph of the Act represents anything other than a good-faith statement of purpose"); Lemon, 403 U.S. at 613 (determination that the statutes clearly state the legislative intent). 
purposes that readily can be implied from the statute ${ }^{28}$ or found in the legislative history. ${ }^{29}$

It appears that if the Court finds any secular legislative purpose for a statute, the statute will pass the secular purpose test. ${ }^{30}$ This tendency has been particularly evident in cases involving statutes granting aid to sectarian schools; purposes such as providing a fertile educational environment, ${ }^{31}$ promoting pluralism and diversity among public and nonpublic schools, ${ }^{32}$ and enhancing the quality of secular education in all schools $^{33}$ are acceptable legislative purposes for statutes that aid sectarian schools. Put simply, the Court is reluctant to attribute unconstitutional inotives to state legislatures. ${ }^{34}$ As a result, the secular purpose test provides minimal assistance in determining whether statutes that provide aid to sectarian schools are unconstitutional.

\section{B. The Primary Effect Test.}

In the second part of the Lemon test, the Court shifts its focus from the legislature's imtent to the statute's primary effect. Using a neutrahity analysis, this test requires a showing that the law's principal or primary effect neither advances nor inhibits rehigion. ${ }^{35}$ In applying the test, the Court has held statutes providing benefits to sectarian schools unconstitutional when they further the religious mission of the schools. ${ }^{36}$ There are two ways a statute will be found to have this impermissible effect: first, if its aid directly benefits a sectarian function of the school, and second, if the aid is so substantial that it benefits the entire sectarian enterprise. ${ }^{37}$

28. See Wolman v. Walter, 433 U.S. 229, $236 \&$ n.5 (1977) (purpose implied from clause restricting aid to nonreligious activities).

29. See Meek v. Pittenger, 421 U.S. 349, 363, 367-68 (1975) (purpose formd in legislative findings); Committee for Pub. Educ. \& Religious Liberty v. Nyquist, 413 U.S. 756, 773 (1973) (statement of legislative purpose appended to statute).

30. See Lynch v. Donnelly, 104 S. Ct. 1355, 1362 (1984) ("[t]he Court has invalidated legislation or governmental action on the ground that a secular purpose was lacking, but only when it lias concluded there was no question that the statute or activity was motivated wholly by religious considerations").

31. Wolman v. Walter, 433 U.S. 229,236 (1977).

32. Committee for Pub. Educ. \& Religious Liberty v. Nyquist, 413 U.S. 756, 773 (1973).

33. Meek v. Pittenger, 421 U.S. 349, 363 (1975); Lemon v. Kurtzman, 403 U.S. 602, 613 (1971).

34. Mueller v. Allen, 103 S. Ct. 3062, 3066 (1983).

35. See Lemon, 403 U.S. at 612.

36. E.g., Committee for Pub. Educ. \& Religious Liberty v. Nyquist, 413 U.S. 756, 794 (1973) (striking down provision of New York law authorizing direct money grants froin state to nonpublic schools for inaintenance and repair of school facilities).

37. See, e.g., id. at 775-76, 783 and n.39 (Court examines statute to determine whether it aids religious mission of an institution; a statute may be upheld if the aid to the religious aspect of institution is immaterial and indirect). 
Statutes that provide aid to sectarian schools do not necessarily have the impermissible effect of furthering rehgion. ${ }^{38}$ The Court has acknowledged that sectarian schools have two functions-a secular function and a sectarian function. ${ }^{39}$ Aid that is directed exclusively to the secular function of sectarian schools is permissible because it does not have the primary effect of furthering the rehgious missions of the schools. Thus, the Court has upheld statutes that provide transportation, ${ }^{40}$ secular school books, ${ }^{41}$ and diagnostic services ${ }^{42}$ to sectarian schools, finding that such benefits aid secular functions. That these types of aid would make it more likely that some students would attend sectarian schools was not an effect that, in itself, violated the test. ${ }^{43}$

In applying the primary effect test, however, the Court has strictly scrutinized statutes to determine whether there is any aid that serves a sectarian function. To pass the test, the secular function receiving the benefit inust be "identifiable and separable" froin the sectarian functions; 44 if aid flows to a school program that has both secular and sectarian characteristics it will not pass the test. For example, the Court invalidated a state program to reimburse nonpublic schools for the costs of giving examinations because it found a "substantial risk that these examinations, prepared by teachers under the authority of rehgious institutions, will be drafted with an eye, unconsciously or otherwise, to inculcate students in the religious precepts of the sponsoring church." 45 An amended version of the prograin that hited reimburseinent to costs associated with state standardized testing, however, sur-

38. See Meck v. Pittenger, 421 U.S. 349, 359 (1975); Committec for Pub. Educ. \& Religious Liberty v. Nyquist, 413 U.S. 756, 771 (1973); Walz v. Tax Comm'n, 397 U.S. 664, 670-72 (1970).

39. Board of Educ. v. Allen, 392 U.S. 236, 245 (1968); $c f$. Pierce v. Society of Sisters, 268 U.S. $510,534-36$ (1925) (sectarian schools provide adequate secular education; state interest in secular education did not require all children to attend public schools).

40. Everson v. Board of Educ., 330 U.S. 1, 17 (1947). The Court has limited transportation reimbursement to the expense of transporting a child to and from school and has invalidated reimbursement for the costs of field trips, finding that there is no assurance that a field trip will not further sectarian goals. Wolman v. Walter, 433 U.S. 229, 253-54 (1977).

41. Wolman v. Walter, 433 U.S. 229, 236-38 (1977); Mcek v. Pittenger, 421 U.S. 349, 361-62 (1975); Board of Educ. v. Allen, 392 U.S. 236, 248 (1968).

42. Wolman v. Walter, 433 U.S. 229, 244 (1977). In Wolman, the Court also found that therapeutic services could be provided to sectarian school children if the services were provided at a neutral sitc. The Court distinguished therapeutic services froin diagnostic services, finding that a therapist "may establish a relationship with a pupil in which there might bc opportunities to transmit ideological views." Id. at 247. Similar services at a neutral site away from the "pervasive atmosphere of a rehigious institution" were found to be permissible. Id.

43. Meek v. Pittenger, 421 U.S. 349, 360 (1975); Board of Educ. v. Allcn, 392 U.S. 236, 244 (1968); Everson v. Board of Educ., 330 U.S. 1, 17 (1947). For a discussion of the holding in Everson, see supra note 20.

44. Levitt v. Committee for Pub. Educ. \& Religious Liberty, 413 U.S. 472, 480 (1973).

45. Id. 
vived the Court's strict scrutiny in a subsequent case. ${ }^{46}$ In this later case, the Court concluded that the inability of the sectarian schools to control the test eliminated any possibility that the test would serve a sectarian function. ${ }^{47}$

Aid that solely benefits a secular function may, nevertheless, impermissibly further the religious mission of a school. In Meek v. Pittenger, ${ }^{48}$ for example, the Court held that state loans of instructional materials and equipment to sectarian schools were impermissible despite the non-ideological nature of the materials. ${ }^{49}$ The Court found that the loans constituted "[s]ubstantial aid to the educational function of such schools . . . [that] . . . necessarily result[ed] in aid to the sectarian school enterprise as a whole."50 Thus, to satisfy the primary effect requirement, aid to sectarian schools inust not only be limited in focus to the secular functions of the school, but it unust also be limited in size.

Realizing that the primary effect test limited direct state aid to sectarian schools to a few narrowly defined areas, states have attempted to circuinvent the test by providing aid indirectly to the schools through benefits to parents of nonpublic school children. The Supreme Court, however, has been reluctant to distinguish between direct and indirect aid in its test, reasoning that such a distinction would exalt form over substance. For exainple, the Court invalidated loans of educational materials and equipment to parents, finding that the prograin was in substance the same as the prograin found unconstitutional in Meek. ${ }^{51}$

Statutes providing tuition grants to parents ${ }^{52}$ and tax credits for tuition ${ }^{53}$ have also been invalidated by the Court. In eacli of these statutes the state had granted a class of citizens-the parents of children

46. Committee for Pub. Educ. \& Religious Liberty v. Regan, 444 U.S. 646, 654-57 (1980).

47. Id. The New York statute required the nonpublic schools to maintain coinplete records of the costs incurred and provided that the State Department of Audit and Control slould inspect the records at regular intervals. Id. at 659-60.

48. 421 U.S. 349 (1975).

49. Id. at 365-66 (inaterials included maps, charts and laboratory equipment).

50. Id. at 366 .

51. Wolman v. Walter, 433 U.S. 229,250 (1977). The Court coinpared the indirect aid program to the direct aid program in $M e e k$ and found that although there was a "teclmical change in legal bailee," the equipment was substantially the same, it was used im a similar manner, and in both programs it was stored and distributed on the school premises. Id.

52. Sloan v. Lemon, 413 U.S. 825, 830-33 (1973); Committee for Pub. Educ. \& Religious Liberty v. Nyquist, 413 U.S. 756, 780-89 (1973).

53. Committee for Pub. Educ. \& Religious Liberty v. Nyquist, 413 U.S. 756 (1973). One of the benefits at issue in Nyquist was in the form of a tax deduction. The Court, however, concluded that its effect was that of a tax credit. Id. at 789 . The Court specifically reserved the question whether a true tax deduction would violate the establishment clause. Id. at 790 n.49. 
attending nonpublic schools-a special benefit. ${ }^{54}$ In analyzing the primary effect of these statutes the Court focused on the nature of the benefitted class. Finding that the vast majority of nonpublic schools were sectarian, ${ }^{55}$ the Court concluded that the primary effect of each statute was to benefit a class that was pervasively sectarian im nature..$^{56}$ Such an effect was unconstitutional because it destroyed the neutrality required to pass the primary effect test. ${ }^{57}$

In summary, the primary effect test requires close scrutimy of any statute that provides aid to sectarian schools or to the parents of children attending such schools. The Court has invalidated these statutes in three situations: if the aid benefits the sectarian function of the schools, if it substantially aids the schools as institutions, or if it benefits a class of citizens that is pervasively sectarian.

\section{The Entanglement Test.}

In contrast to the "primary effect" inquiry, the third part of the Lemon test exammes the form of the relationship tetween government

54. Sloan v. Lemon, 413 U.S. 825, 832 (1973); see Committee for Pub. Educ. \& Religious Liberty, 413 U.S. 756, $782 \mathrm{n} .38,794$ (1973) ("grants to parents of private school children are given in addition to the right that they leave to send their children to public schools 'totally at staff expense' "); see also Kosydar v. Wolman, 353 F. Supp. 744, 761 (S.D. Ohio 1972) ("For the state to allow a credit to the parent who forgoes use of the provided public facility in order to send his child to a private school is a grant to that taxpayer of a relative economic advantage when compared to taxpayers generally."), affd mem. sub nom. Grit v. Wolman, 413 U.S. 901 (1973).

55. In Sloan, the Court accepted a lower court's finding that religious organizations controlled over $90 \%$ of nonpublic schools in Pennsylvania. Sloan v. Lemon, 413 U.S. 825, 830 (1973). Similarly, in Nyquist, the Court found that approximately $85 \%$ of New York's nonpublic schools were church affiliated. Committee for Pub. Educ. \& Religious Liberty v. Nyquist, 413 U.S. 756, 768 (1973). In Kosydar, the district court found that $98 \%$ of the nonpublic scliools in Ohio were church affiliated. Kosydar v. Wolman, 353 F. Supp. 744, 762 (S.D. Ohio 1972), aff'd mem. sub nom. Grit v. Wolman, 413 U.S. 401 (1973).

56. Sloan v. Lemon, 413 U.S. 825, 832 (1973); Committee for Pub. Educ. \& Religious Liberty v. Nyquist, 413 U.S. 756, 783 (1973); see also Kosydar v. Wolman, 353 F. Supp. 744, 762 (S.D. Ohio 1972) (as the private schools were predommantly sectarian, "it simply defies reason to say that the statute does not aid sectarian schools"), aff'd mem. sub nom. Grit v. Wolman, 413 U.S. 901 (1973).

57. The Court found that whether viewed as incentives to parents to send their children to sectarian schools or as rewards for having done so, the statutes' consequences were to preserve and support religious institutes. Sloan v. Lemon, 413 U.S. 825, 832 (1973); see also Counnittee for Pub. Educ. \& Religious Liberty v. Nyquist, 413 U.S. 756, 786 (1973) (impact is the same "[w] hether labeled a reimbursement, a reward, or a subsidy"); Kosydar v. Wolman, 353 F. Supp. 744, 767 (S.D. Ohio 1972) ("state may not, consistent with the Establishment Clause, confer unrestricted economic benefit upon a class of predominantly sectarian character in a manner which tends to advantage them"), aff'd mem. sub nom. Grit v. Wolman, 413 U.S. 901 (1973). In Nyquist, the Court also found that with these indirect aid statutes there was "no endeavor "to guarantee the separation between secular and religious educational functions and to ensure that State financial aid support only the former.' " Committee for Pub. Educ. \& Religious Liberty v. Nyquist, 413 U.S. 756, 783 (1973) (quoting Lemon v. Kurtzman, 403 U.S. 602, 613 (1971)). 
and religion "for the light it casts on the substance." 58 If a state statute requires an "administrative entanglement"-governmental intrusion into religion-or a "political entanglement"-religious intrusion into government-the statute will fail the entanglement test. ${ }^{59}$

Administrative entanglement often results from compliance with the requirements of the primary effect test. As shown above, the primary effect test requires that aid to sectarian schools be limited to the secular functions of the school. ${ }^{60}$ As a result, many statutes restrict the aid program to ensure that state aid is not flowing to sectarian functions. State surveilance is often required to ensure compliance with these statutory restrictions. ${ }^{61}$ Surveillance, however, can be viewed as a governmental intrusion into religion. Therefore, the Court finds an impermissible administrative entanglement whenever a "comprehensive, discriminating and contmuing state surveillance will inevitably be required to ensure that these restrictions are obeyed."62 In other words, the entanglement test limits aid available to sectarian schools to programs requiring minimal surveillance. ${ }^{63}$

The entanglement test also focuses on the potential of a statute to create political division along religious lines-a "political entanglement." 64 To pass this part of the test, the divisive potential of a statute

58. Lemon, 403 U.S. at 614 . In Lemon, the Court found that a test for administrative entanglement required an examination of "the character and purposes of the institutions that are benefited, the nature of the aid the State provides, and the resulting relationship between the government and the religious authority." Id. at 615 .

59. See Walz v. Tax Comin'n, 397 U.S. 664, 675 (1970) ("The hazards of churches supporting government are hardly less in their potential than the hazards of government supporting churches; each relationship carries some involvement rather than the desired insulation and separation."); see also Cominent, Mueller v. Allen: Do Tuition Tax Deductions Violate the Establishment Clause?, 68 Iowa L. Rev. 539, 554-55 (1983); Cominent, Tax Deductions for Parents of Children Attending Public Schools and Nonpublic Schools: Mueller v. Allen, 71 KY. L. J. 685, 690-91 (198283).

60. See supra notes $44-57$ and accompanying text.

61. For examples of aid programs that require state surveillance, see infra note 63.

62. Lemon, 403 U.S. at 619.

63. Examples of aid requiring minimal surveillance are textbook loans, Board of Educ. v. Allen, 392 U.S. 236, 244-45 (1968) (one-time test is required to determine if textbooks are secular in nature), and diagnostic services, Wolman v. Walter, 433 U.S. 229, 244 (1977) (Court found no need for excessive surveillance). In contrast, aid programs that have been invalidated because they required continuing state surveillance to ensure that the benefit was not used for sectarian purposes include teacher salary suppleinents, Lemon v. Kurtzman, 403 U.S. 602, 615-24 (1971), funding of teachers providing auxiliary services, Meek v. Pittenger, 421 U.S. 349, $367-72$ (1975), and reimbursement of testing costs, Levitt v. Committee for Pub. Educ. \& Religious Liberty, 413 U.S. 472, 480-81 (1973).

64. Lemon, 403 U.S. at 622 ("Ordimary political debate and division, however vigorous or even partisan, are normal and healthy manifestations of our democratic systein of government, but political division along religious limes was one of the primcipal evils against which the First Amendment was intended to protect."); see Walz v. Tax Comm'n, 397 U.S. 664, 694 (1970) 
unust be minimized. The Court has considered two factors in determining the degree of political entanglement inherent in a statute: first, the size and diversity of the benefitted class, and second, whether the statute requires continuing appropriations. ${ }^{65}$ Increasing the size and religious diversity of the benefitted class minimizes the possibility that political divisions created by the statute will be based along religious lines. ${ }^{66}$ Similarly, political fraginentation can also be minimized by eliminating any continuing appropriations requireınent from a statute, thereby avoiding the possibility of repeated political battles that accoinpany appropriations. ${ }^{67}$ These factors, however, merely provide indications of a statute's potential for creating political division. The Court has admitted that political entanglement decisions are "difficult to document" 68 and that other factors such as the size and nature of the actual controversy created by a statute might also be considered by a court. ${ }^{69}$

\section{MUELLER V. ALLEN: A Less Strict Standard of SCRUtiny}

In Mueller v. Allen, ${ }^{70}$ the United States Supreine Court upheld a Minnesota statute allowing state taxpayers to claim a deduction for expenses incurred for "tuition, textbooks and transportation" in sending dependents to elementary or secondary school. ${ }^{71}$ Although parents of children attending sectarian schools are the primary beneficiaries of Minnesota's statute, ${ }^{72}$ parents of children attending public schools are

(Harlan, J., concurring) (purpose of the establishment clanse was to prevent the degree of political entanglement that could strain a political system to its breaking point); Everson v. Board of Educ., 330 U.S. 1, 8-11 (1947) (establishment clanse was created in response to the memory of civil strife and political turmoil generated by competition between religious sects for political and religious supremacy in the colonies).

65. See Lemon, 403 U.S. at 623; Tilton v. Richardson, 403 U.S. 672,688 (1971).

66. See Lemon, 403 U.S. at 623; see also Tilton v. Richardson, 403 U.S. 672, 688 (1971); Kosydar v. Wolman, 353 F. Supp. 744, 753-54 (S.D. Olio 1972), aff'd mem. sub nom. Grit v. Wolman, 413 U.S. 901 (1973).

67. See Meek v. Pittenger, 421 U.S. 349, 372 (1975); Lemon, 403 U.S. at 623.

68. Tilton v. Richardson, 403 U.S. 672,688 (1971).

69. In Nyquist, the Court suggested another factor: "Aid programs of any kind tend to become entrenclied, to escalate in cost, and to generate their own aggressive constituencies. And the larger the class of recipients, the greater the pressure for accelerated increases." 413 U.S. at 797 (footnote omitted).

70. 103 S. Ct. 3062 (1983).

71. MinN. Stat. $\$ 290.09(22)$ (1982). For the text of the statute, see supra note 11.

72. Approximately 820,000 students attended the Minnesota public schools during the 1982 83 school year. Mueller, $103 \mathrm{~S}$. Ct. at 3064 . The Minnesota Department of Education estimated that monies received by public scliool districts that are clraracterized as tuition-i.e., fees which may be charged to pupils for services and inaterials pursuant to MiNN. STat. $\$ \S 120.06,123.39$, and 120.74 -totalled $\$ 2,005,142$, an average of $\$ 2.49$ per public school student. Brief for Petitioners at 8-9, Mueller v. Allen, 103 S. Ct. 3062 (1983). Few public scloool students, however, actually are charged tnition in the ordinary sensc. Although no statistics are cited for the most recent sclrool years, in the 1978-79 school year only 79 pupils paid tuition in Minnesota, and in the 1977 . 
also eligible for aid under the statute. ${ }^{73}$ The Minnesota statute thus neutrally extends benefits to any parent who incurs deductible expenses. ${ }^{74}$ The apparent advantage to nonpublic school parents results froin a separate decision by the state to provide free schools, textbooks and transportation to children attending public schools, ${ }^{75}$ thereby eliminating the possibility, in most cases, that the parent of a child attending public school will incur deductible expenses.

The Court structured its opinion in Mueller in the form of the traditional Lemon three-part test. ${ }^{76}$ However, the Court applied a different level of scrutiny to the Minnesota tax statute than it previously

78 school year only 40 students were charged. Joint App. at 35, Mueller v. Allen, 103 S. Ct. 3062 (1983).

During the 1979-80 school year almost 91,000 students attended non-public schools in Minnesota; $95 \%$ of those students attended schools that consider themselves to be sectarian. Mueller, $103 \mathrm{~S}$. Ct. at 3064-65. From these statistics it seems clear that the bulk of the Minnesota tax deduction benefit is extended to the parents of children attending nonpublic schools, the vast majority of which are sectarian in character.

73. The tuition tax deduction is available to the parents of public school children who are required to pay tuition. In Minnesota, public school students are required to pay tuition if they attend public schools outside the school district of their residence, MINN. STAT. \$ 123.39(5) (1982), and in a number of other situations. See Mueller v. Allen, 514 F. Supp. 998, 1000 (D. Minn. 1981) (district court findings of fact concerning scope of Minnesota tuition deduction).

Similarly, the transportation deduction provides a benefit to the parents of some public school students. The district court in Mueller found that deductible transportation expenses included the cost of transporting students who he in one district but attend school in another, the cost of transporting students in school districts that do not provide free transportation (free transportation to public schools in Minnesota is provided only at the option of the local school board, MinN. STAT. ANN. \$ 123.39(1) (West Supp. 1984)), and the cost of transporting students who do not qualify for free transportation because of their proximity to school. Mueller, $514 \mathrm{~F}$. Supp. 998, 1000 (1981). In addition, the Minnesota Department of Revenue has ruled that the cost of a required field trip is also a deductible transportation expense. Joint App. at 19, Mueller v. Allen, $103 \mathrm{~S}$. Ct. 3062 (1983). Thus, in the above situations, parents of public school students mcur expenses and receive tax deductions under the Minnesota statute.

The textbook deduction also benefits the parents of pubhic school children because it applies not only to the costs of secular textbooks (textbooks in Minnesota are provided free to public school students, MINN. STAT. $\S 123.35(2)$ (1982)), but also to other necessary expenses sucli as the cost of tennis shoes and sweat suits for physical education; rental fees paid to the school for cameras, ice skates, calculators, and musical instruments; the cost of supplies necessary in shop and home econoumics courses; and the cost of pencils and notebooks for class. Mueller, 514 F. Supp. at 1000 .

74. See Mueller v. Allen, 103 S. Ct. 3062, 3065 (1983).

75. The general policy of the state of Minnesota in providing free public school education is stated in MINN. STAT. ANN. \& 120.72 (West Supp. 1984). Local school boards are required to furnish free textbooks to public school students, MINN. STAT. $\S 123.35$ (2) (1982), and they have an option to provide free transportation if funds are available in the district. MINN. STAT. ANN. \$123.39(1) (West Supp. 1984).

76. One author has suggested that the three-part test often "serves more as a franework for structuring opinions than as a guidepost for determining outcome." Young, Constitutional Validity of State Aid to Pupils in Church-Related Schools-Internal Tension Between the Establishment and Free Exercise Clauses, 38 OHo ST. L.J. 783, 788 (1977). 
had applied when utilizing the Lemon test. Apparently, the Court reasoned that the benefit conferred upon religious institutions by the tax deduction was of such an attenuated nature that a milder standard of scrutiny was appropriate. ${ }^{77}$ This new standard of scrutiny actually affects only two parts of the Lemon test; the secular purpose test remains unaffected because the standard of scrutimy required in that test was already low. ${ }^{78}$ The effects on the other two parts of the Lemon test will be examined separately.

\section{A. The Primary Effect Test in Mueller.}

The level of scrutiny required under the primary effect test for statutes allowing tax deductions for tuition was the major issue presented by the conflict in the circuit courts that necessitated Supreme Court review in Mueller. ${ }^{79}$ In Rhode Island Federation of Teachers v. Norberg, ${ }^{80}$ the United States Court of Appeals for the First Circuit confronted a Rhode Island statute virtually identical to the Minnesota statute at issue in Mueller. ${ }^{81}$ Applying the strict level of scrutiny required by the traditional primary effect test, ${ }^{82}$ the court looked beyond

77. The dividing line between the new mild standard of scrutiny and the traditional strict standard of scrutiny might appear to be arbitrarily drawn. In a parallel situation, however, the Court drew a similar line between aid to primary and secondary schools, which remains subject to a traditional level of scrutiny, and aid to higher education, which is subject to a milder standard. In determining the constitutionality of state aid to colleges and universities, the Court has emphasized the character of the institutions, rather than the form of aid supplied. See Roemer v. Board of Pub. Works, 426 U.S. 736, 764 (1976). The Court found the following differences between college and pre-college education: "College students are less susceptible to religious indoctrimation; college courses tend to entail an internal discipline that inherently limits the opportunities for sectarian influence; and a high degree of academic freedoin tends to prevail at the college level." Id. at 750; Tilton v. Richardson, 403 U.S. 672, 686 (1971) ("The skepticism of the college student is not an inconsiderable barrier to any attempt or tendancy to subvert the Congressional objectives and limitations."); see Hunt v. McNair, 413 U.S. 734, 743-44 (1973). In essence, the Court decided to limit the strict scrutiny requirements of the Lemon test to institutions that had a strong sectarian influence. Thus, the Court drew a line between college and pre-college aid, calling the form of aid irrelevant and placing the burden on the party opposing college aid to show that the benefitted institutions were "pervasively sectarian." See Roemer, 426 U.S. at 750-53, 759-60.

In Mueller, the Court emphasized the form of the challenged aid rather than the character of the institution benefitted. As in the college aid cases, the Court drew a line, this time between tax deductions and other forms of aid. In drawing this line, the Court recognized that at a certain point the benefits provided to religion became so attenuated that the strict scrutiny required by the traditional Lemon test was inappropriate. It is important to notc that in Mueller the tax deduction was neutrally available to all, inaking an analysis of the character of the benefitted institutions unnecessary. Thus, as in the college aid cases, the party opposing a tax deduction should bear the burden of proving that the benefitted class is pervasively sectarian.

78. See supra notes 30-34 and accompanying text.

79. See supra notes 9-11 and accompanying text.

80. 630 F.2d 855 (1st Cir. 1980).

81. See supra note 11 (texts of the two state tax deduction statutes).

82. See supra notes $44-57$ and accompanying text. 
the facial neutrahity of the statute. It used statistical analysis to conclude that "the Rhode Island tax deduction would confer a tax benefit along nearly solid sectarian lines." 83 In essence, the court used a de facto analysis ${ }^{84}$ to determine the character of the affected class of beneficiaries under the statute. Concluding that the majority of the de facto beneficiaries were parents of sectarian students, the court found the similarities to Committee for Public Education and Religious Liberty $v$. Nyquist ${ }^{85}$ inescapable and therefore held the Rhode Island statute unconstitutional.

In Mueller v. Allen, the Court of Appeals for the Eighth Circuit reached a contrary result with facts and statistics almost identical to those in Norberg. ${ }^{86}$ That court based its decision on a finding that the statute was facially neutral, ${ }^{87}$ thereby imphicitly accepting the defendant's argument that "a de jure, not a de facto, analysis is the proper test in ascertaining the breadth of the benefitted class." 88

In affirming the lower court's decision, the Supreine Court stressed the statute's broad language that made the tax deduction for educational expenses available to all parents. ${ }^{89}$ The Court also rejected the petitioner's statistical analysis of the de facto class of beneficiaries: "We would be loath to adopt a rule grounding the constitutionality of a facially neutral law on annual reports reciting the extent to which various classes of private citizens claimed benefits under the law."90 Because the tax deduction was available to all parents, the Court

83. Norberg, 630 F.2d at 860 . In comparing the Rhode lsland tax statute to the tax exemption upheld in Walz v. Tax Comm'n, 397 U.S. 664 (1970), and the tax "credit" program held unconstitutional in Committee for Public Educ. \& Rehgious Liberty v. Nyquist, 413 U.S. 756 (1973), the Norberg court held:

[T] he district court's finding that the overwhelming majority of the parents eligible for the tuition tax deduction send their children to sectarian schools denies the tuition deduction the protection of $\mathrm{Walz}$ and places it . . . within the proscription of Nyquist. Absent a class having primarily secular characteristics ... it cannot be said that the advantages fiowing from the statute to the parents of sectarian school students will be incidental to secular ends and effects.

Norberg, 630 F.2d at 861 (citation ommitted).

84. For a discussion of de facto and de jure analyses, see infra note 88.

85. 413 U.S. 756 (1973).

86. Mueller v. Allen, 676 F.2d 1195, 1200-01 (8th Cir. 1982). The court recognized the similarities to Norberg but disagreed with the Norberg court's analysis of prior Supreme Court cases. Id. at 1201 .

87. See id. at 1204

88. Id. at 1199. A "de facto" analysis requires a factual imquiry into the character of the class of citizens actually benefitted by a statute. A "de jure" analysis requires only scrutiny of the statute itself to determine the character of the class of citizens ehgible for the benefit. See Comment, Mueller v. Allen: Do Tuition Tax Deductions Violate the Establishment Clause?, 68 IowA L. Rev. 539, 549 (1983).

89. Mueller, $103 \mathrm{~S} . \mathrm{Ct}$. at 3068.

90. Id. at 3070 . 
coinpared the Minnesota statute to similarly broad statutes upheld in earher opinions ${ }^{91}$ and distinguished decisions that held other types of tax benefits unconstitutional. 92

The Court identified two features of the Minnesota tax deduction that justified the less strict level of scrutiny inherent in a de jure analysis: first, the benefit conferred on religion by the granting of a tax deduction to individual citizens is highly attenuated, ${ }^{93}$ and second, this attenuated benefit to rehigion is subject to the private choices of individual parents. ${ }^{94}$ The Court then considered these features when analyzing the purposes of the establishment clause, and concluded that "the historic purposes of the clause simply do not encompass the sort of attenuated financial benefit, ultimately controlled by the private choices of individual parents, that eventually flows to parochial schools from the neutrally available tax benefit at issue in this case."95

Thus, in Mueller, the Court apphed the primary effect test in a fundamentally different way. Rather than scrutinizing a statute for its de facto effect, the Court apparently was willing to presume a secular effect when it determined from a de jure analysis that a broad class of citizens were eligible for the benefit. The Court's justifications for utilizing a de jure analysis, ${ }^{96}$ however, suggest that this less strict standard of scrutimy should be apphed only to a narrow range of statutesthose statutes that benefit rehion in a highly attenuated inaimer.

91. See id. at 3070 \& n.10; see also Board of Educ. v. Allen, 392 U.S. 236, 248 (1968) (approving loans of secular educational materials to all students); Everson v. Board of Educ., 330 U.S. 1, 16 (1947) (approving statute reimbursing all parents for school transportation costs).

92. See id. at 3068 (citing Committee for Pub. Educ. \& Religious Liberty v. Nyquist, 413 U.S. 756, 794 (1973) (tax "credit" for parents of children attendimg nonpublic schools violates primary effect test)); Pubbic Funds for Pub. Schools v. Byrne, 590 F.2d 514, 518 (3d Cir. 1979) (tax deduction for parents of children attending nonpublic schools violates primary effect test), aff d mem., 442 U.S. 907 (1979); Kosydar v. Wolman, 353 F. Supp. 744 (S.D. Ohio 1972) (tax credit for parents of children attending nonpublic schools violates primary effect test), affd mem. sub nom., Grit v. Wolman, 413 U.S. 901 (1973).

93. Mueller, 103 S. Ct. at 3069. But cf. Committee for Pub. Educ. \& Religious Liberty v. Nyquist, 413 U.S. 756, 790-91 (1973) (tax credit has same effect as a tuition grant because it encourages and rewards parents for sending a child to a nonpublic school); Kosydar v. Wolman, 353 F. Supp. 744, 762 (S.D. Ohio 1972) (tax credit aids rehgion if it allows pareuts to send their children to nonpublic schools that they could not otherwise have afforded), aff'd mem. sub nom. Grit v. Wolman, 413 U.S. 901 (1973).

94. Mueller, $103 \mathrm{~S}$. Ct. at 3069. The Court could have concluded that the availability of the tax deduction to all parents would create a demand for a variety of nonpublic schools. Thus, looking beyond the present class of de facto beneficiaries under the Minnesota statute, the Court might have envisioned the existence in the future of a broad class of de facto beneficiaries without substantial sectarian characteristics.

95. $I d$.

96. See supra notes $93-95$ and accompanying text. 


\section{B. The Entanglement Test as Applied in Mueller.}

The mild standard of scrutiny applied in the primary effect test was paralleled by the minimal scrutiny applied in Mueller to the entangleinent test. This less strict scrutiny was not clearly evident in the Court's application of the administrative entangleinent test because even under a traditional level of scrutiny, a tax deduction creates no inajor administrative entangleinent problein. ${ }^{97}$ Even so, the Court's analysis in this part of the test was noticeably brief; ${ }^{98}$ altlough the Court did address the administrative entanglement problems inherent in the Minnesota textbook deduction, it neglected to address the possible entanglement problems related to deductions for instructional materials and equipment that are imcluded in the textbook deduction. ${ }^{99}$ This cursory examination suggests that the Court was applying a less strict standard of scrutiny.

In addition to reducing the level of scrutiny required under an administrative entanglement analysis, the Court further weakened the entanglement test by eliminating the political entanglement test entirely for statutes that provide aid indirectly. The Court concluded from an examination of the cases distinguished in Lemon ${ }^{100}$ that the political entangleinent test is "confined to cases where direct financial subsidies are paid to parochial schools or to teacliers in parochial schools."101 While a line between indirect and direct aid may appear arbitrary, it

97. The possibility of administrative entanglement is lessened considerably because a tax deduction directly benefits parents rather than schools. Therefore, any state surveillance would be directed not at the school, but at the parent, substantially lessening the risk that the government would intrude into religious affairs. This argument is based on an assumption that the state would have to monitor only the parents' tax deductions. In reality, however, textbook and tuition expenses originate in decisious made at the school, and, therefore, any state surveillance of a parent's tax deductions will necessarily require an analysis of the decisions made by the school. Thus, under examination, this argument does not hold up. Under the Court's rather limited scrutiny in Mueller, it wonld seein that so long as there is no readily apparent entanglement, the statute under consideration will pass the administrative entanglement test.

98. The Court's analysis was contained in a single paragraph. See Mueller, $103 \mathrm{~S}$. Ct. at 3071.

99. The Court concluded that the Minnesota textbook deduction was similar to textbook loans upheld in previous opinions. Id. (citing three cases). Before Mueller, the Court had not addressed the possible entanglement created by statutes providing instructional materials and equipment because such statutes had never passed the primary effect test. $C f$. Wolman v. Walter, 433 U.S. 229, 250 (1977) (aid provided held to have primary effect of providing direct and substantial advanceinent of the sectarian enterprise); Meek v. Pittenger, 421 U.S. 349, 365 (1975) (same). The Minnesota textbook deduction clearly included such items. See supra note 73.

100. The political entanglement test originated in Lemon, 403 U.S. at 622-23.

101. Mueller, $103 \mathrm{~S}$. Ct. at $3071 \mathrm{n} .1 \mathrm{l}$. The Court reaffirmed this view in Lynch v. Donnelly, $104 \mathrm{~S}$. Ct. 1355, 1364-65 (1984) ("This case does not involve a direct subsidy to church-sponsored schools or colleges, or other religious institutions, and, hence, no inquiry into potential political divisiveness is even called for."). 
seems consistent with the Court's earlier conclusions that the nature of the benefit to religion was attenuated and that the class of beneficiaries was broad. These conclusions allow a presumption that the tax statute will not have a divisive political effect. 102

Thus, the Mueller Court's entanglement analysis significantly differed from the traditional entanglement test. The standard of scrutimy under an administrative entanglement test was lowered to require only a superficial examination. Moreover, the political entanglement test was eliminated for statutes providing imdirect aid to sectarian schools. These changes parallel similar changes made in the primary effect test, and would appear to be the result of the Court's conclusion that a tax deduction to parents merely results in an attenuated benefit to religion.

\section{The Possible Effects of MUELLER}

The less strict standard of scrutiny applied in Mueller suggests that any tax deduction for educational expenses that neutrally extends its benefits to all parents ${ }^{103}$ will survive a constitutional attack based on the establishment clause. The majority opinion indicates that a tax deduction benefittimg the parents of sectarian school students will be subject to a de jure effect test rather than the traditional de facto effect test. 104 Under this de jure analysis, the Court no longer requires a statutory benefit to be limited strictly to the secular functions of the schools. For example, the Minnesota statute in Mueller allowed deductions for the transportation expenses of school field trips and deduc-

102. Under the traditional entanglement analysis, when no fnrther legislation is needed to continue the benefit and when the benefitted class is broad, the possibility of political entanglement is considerably less. See supra text accompanying notes 65-67. Nevertheless, pressure to increase or decrease the existing tax benefit could develop conflicts based on religious affiliation. See Committee for Pub. Educ. \& Religious Liberty v. Nyquist, 413 U.S. 756, 797 (1973); Kosydar v. Wolman, 353 F. Supp. 744, 766-67 (S.D. Ohio 1972), affd mem. sub nom. Grit v. Wolman, 413 U.S. 901 (1973). Apparently, the Court's introduction of an additional factor-the attenuated nature of the tax benefit-neutralized this political entanglement argument.

103. It is, however, unclear when the Court will find the required neutrality. In Mueller, the parents of public school children were eligible for tax deductions under the Minnesota statute in certain situations. See supra note 73. A different situation might be presented if a statute purports to benefit all parents, but, in fact, the statute excludes parents of public school children because they never incur deductible expenses. For example, a tuition tax deduction to all parents who pay tuition to any school would appear on its face to be neutral, but if the state provides free public schools without exceptions-im contrast to Minnesota-then the parents of public school children could never be eligible for the deduction. To find that such a statute was not neutral the Court would not be forced to look at statistics showing the type of persons receiving benefits, but instead simply could review the apphicable state statutes to determine if the parents of public school children could ever be eligible. Thus, it is possible that the Court may distinguish Mueller from cases similar to the above example.

104. See supra notes $88-96$ and accompanying text. 
tions for the costs of certain instructional inaterials. ${ }^{105}$ In earlier cases, these categories of aid had been invalidated based on findings that the aid was not restricted to purely secular functions. ${ }^{106}$ Thus, the limitations placed on direct aid to sectarian schools confining the aid to secular functions of the schools ${ }^{107}$ would not appear to apply to statutes providing aid to schools through the indirect method of tax deductions to parents.

Perhaps, however, the Court will place certain limitations on deductible expenses. Charges to parents for purely sectarian activities would certainly be ineligible for a deduction, but so long as the expenses incurred relate to the normal functions of a school it seems clear that the Court will not require a strict analysis of whether a particular funded activity might be used to inculcate religious beliefs. ${ }^{108}$

This approach may be based on an assunption by the Court that the amount of actual tax saving to eacli parent will always be less than the expense required per pupil to fund the secular functions of the school. Under this view, it would be impossible for a tax deduction to benefit the sectarian functions of the school. In Committee for Public Education and Religious Liberty v. Nyquist, the Court rejected this theory in relation to a tax credit. It reasoned that "a mere statistical judgment will not suffice as a guarantee that state funds will not be used to finance religious education." 109 The nature of a tax deduction, however, may allow a different result. As Justice Marshall acknowledged in his Mueller dissent:

The deduction at issue im this case does differ from the tax benefits in Nyquist and our other prior cases im one respect: by its very nature the deduction embodies an inherent limit on the extent to which a state may subsidize religious education. Unlike a tax credit, whicl may wholly subsidize the cost of religious education, if the size of the credit is sufficiently large, or a tax deduction of an arbitrary sum, a deduction of tuition payments from adjusted gross income can never "provide a basis for . . . complete subsidization of . . . religious schools."110

105. See supra note 73.

106. Wolman v. Walter, 433 U.S. 229, 250, 253-54 (1977) (instructional materials and equipment loaned to children or parents and reimbursement to nonpublic schools for the costs of feld trips violate the primary effect test because they do not separate aid to secular functions and aid to sectarian functions); Meek v. Pittenger, 42l U.S. 349, 363-66 (1975) (loans of instructional materials and equipment to nonpublic schools violate the primary effect test).

107. See supra notes $44-57$ and accompanying text.

108. See supra notes $96-97$ and accompanying text.

109. Committee for Pub. Educ. \& Religious Liberty v. Nyquist, 413 U.S. 756, 778 (1973).

110. Mueller, 103 S. Ct. at 3075 n.5 (Marshall, J., dissenting) (emphasis in original). 
This distinction would allow the Court to avoid an analysis of the possible benefits flowing to sectarian functions.

Therefore, in its Mueller decision, the Court has provided the states with a simple and efficient, though imdirect, method for achieving their apparent goal of supportimg nonpublic schools. Rather than providing a variety of programs to fund selected secular functions of nonpublic schools, a state now may achieve the same goal-support of sectarian schools-by providing a single program of tax deductions. Furthermore, Mueller indicates that the types of functions that can be subsidized utilizing tax deductions will not necessarily be limited to purely secular functions. Apparently, in some cases, the state may do indirectly that which it caunot do directly.

The Mueller decision also opens the door for indirect federal aid to nonpublic schools in the form of tax deductions. The existence of two recent bills calling for federal tax credits to parents of children attending private scliools ${ }^{111}$ makes it clear that there is an interest in providing federal aid to nonpublic schools. Because Mueller provides a format for a tax deduction likely to pass constitutional scrutimy, the Court's opimion may encouragc congressional legislation drafted to conform with the Minnesota statute. ${ }^{12}$

\section{Conclusion}

In Mueller v. Allen, the United States Supreme Court held that a specific type of state aid to non-public schools was constitutionally permissible. In holding that the statute at issue did not violate the establisliment clause, the Court applied the Lemon three-part test in a substantially different way, minimizing the level of scrutiny required under both the primary effect test and thc entanglement test. The case, lowever, does not reject the former standard of scrutiny required in the Lemon test. Instead the case illustrates how a Lemon analysis changes when it reaches certain limits. The college aid cases suggest that beyond a certain point the sectarian character of an institution becomes so overshadowed by its secular character that a strict Lemon analysis no longer seems appropriate. ${ }^{113}$ At that poimt, a less strict test has been applied by the Court. In Mueller, the Court has revealed another ex-

111. S. 528, 98th Cong., 1st Sess., 129 ConG. REc. 1335-38 (1983); S. 550, 97th Cong., 2d Sess., 127 Cong. REc. 1514-16 (1981).

112. A federal tax deduction extended to all parents who incur educational expenses would appear facially neutral. The Court, however, might distinguish Mueller based on a finding that in certain states the parents of public schoolchildren could never be eligible for the benefit. See supra note 103 .

113. See supra note 77. 
ception to the strict Lemon standard. Rather than analyzing the nature of the institution, this exception is based on the nature of the benefitwhen the benefit to religion becomes highly attenuated a strict Lemon analysis is no longer necessary.

The approach by the Court is a realistic one. In modern society, the risk of establishing religion through limited aid to religious schools is small. By establishing boundaries for a strict Lemon analysis, the Court recognized the absurdity of blindly adhering to a strict test when the risks of establishing religion lave become minimal. Defining the limits of the strict Lemon test entails an arbitrary line-drawing process, but the line drawn between tax deductions and other forins of aid is sensible. 